International Journal of Industrial and Business Management
(ISSN: 2572-8423)

\title{
Analysis of reasons for audit failure and study of preventive strategies
}

\section{Song Longfei}

School of Economics and Management, Huainan Normal University, Huainan 232001, China

\section{ABSTRACT}

Using 2007-2017, securities regulatory commission announced on the administrative penalty, penalty and certified public accountant firm in the audit failure penalty as the research sample, respectively, from the audit failure of violating the frequency of the auditing standards, registered public accounting firm scale and the relationship between the financial fraud and audit failure three aspects to discusses the reasons of audit failure. It is found that "audit evidence" and "verification" account for a large proportion of audit failures. There is a positive correlation between the size of firms and audit quality, and the proportion of audit failures in "big firms" is low. There is no correlation between financial fraud and audit failure. , In view of the reasons for the audit failure, this paper puts forward some preventive strategies. ,

Keywords: audit failure; Auditing standards; Firm size; Financial fraud
*Correspondence to Author:

Song Longfei

School of Economics and Management, Huainan Normal University, Huainan 232001, China

How to cite this article:

Song Longfei.Analysis of reasons for audit failure and study of preventive strategies. International Journal of Industrial and Business Management, 2019; 3:9.

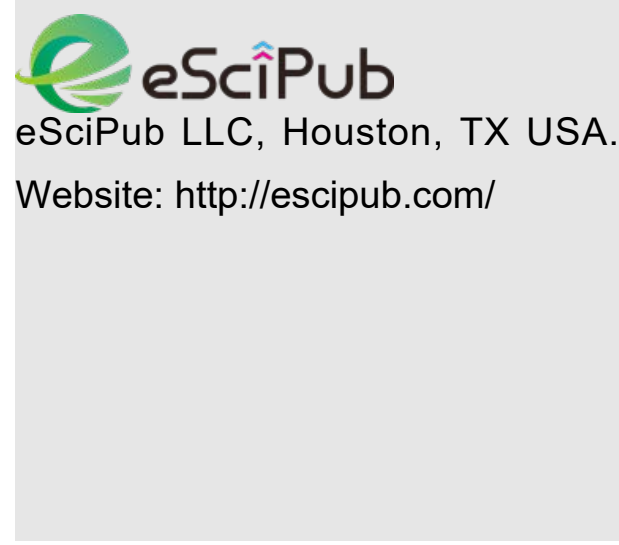




\section{The introduction}

With the sound of modern corporate governance system, shareholders, creditors, governments and other stakeholders obtain corporate information through the main channels of corporate financial reports, accounting information quality determines whether the information obtained by stakeholders can serve for decision-making. The audit report issued by certified public accountants to audit the company's financial report is the main basis for statement users to identify the quality of information. From the data released by China securities regulatory commission, it can be seen that cases of certified public accountants' audit failure occur from time to time, which brings a certain negative impact on the reputation of certified public accountants industry and also affects the healthy development of the capital market. In this paper, the administrative punishment documents from 2007 to 2017 were selected from the administrative punishment decision letters published by the CSRC. The reasons for the audit failure were discussed from three aspects, including audit failure and audit standards, audit failure and scale of accounting firm, audit failure and financial fraud, and the prevention strategies were proposed.

\section{Literature review}

At present, domestic and foreign scholars generally follow the concept definition, cause analysis and preventive measures to study the audit failure. However, the definition of audit failure, the analysis of the causes of audit failure and how to deal with audit failure have not reached a research conclusion that everyone agrees with.

(i)Definition of the concept of audit failure Alvin a. ahrens et al. pointed out in their book auditing: an integrated approach that audit failure is due to the fact that the certified public accountants did not follow the requirements of audit standards in the audit process and made wrong audit opinions. Zheng zhaohui (2001) believes that audit failure means that certified public accountants make mistakes in the course of practice and then form wrong audit conclusions [1]. Chen xi (2012) defined audit failure from the formation requirements of audit failure, and pointed out that the error or inappropriateness of audit results was one of the requirements of audit failure. The second constituent condition of audit failure is that certified public accountants fail to fulfill the duty of diligence or have intentional behaviors in the audit process ${ }^{[2]}$. The definition of audit failure is mainly discussed from two aspects: audit result failure theory and audit process failure theory. The audit result failure theory mainly emphasizes that the certified public accountants fail to pay enough attention to the material misstatement or omission in the financial statements of enterprises and issue audit reports inconsistent with the facts. The audit process failure theory emphasizes that auditors fail to follow audit standards and express improper audit opinions.

(ii) Cause analysis of audit failure

Domestic and foreign scholars mainly analyze the reasons of audit failure from three aspects: accounting firms, auditees and audit standards. (De Angelo, 1981; Chen hanwen et al., 2003) believed that the lack of independence in the audit process was the main reason for the audit failure ${ }^{[3-4]}$. Ma LAN and wang yanming (2003) believe that audit failure is not necessarily related to business failure, and that audit failure is mainly because certified public accountants fail to pay enough attention to possible phenomena in the audit process and publish wrong audit conclusions ${ }^{[5]}$. Based on the COSO 
report, li ruoshan (2005) studied the traditional audit failure and enterprise innovation, and believed that when facing the survival pressure, enterprises would use innovative means to conduct accounting fraud, which would lead to the occurrence of audit failure ${ }^{[6]}$. Li ping and wang xiaomin (2011), through analyzing the punishment documents of China securities regulatory commission, believe that fraud by the management level of listed companies is the main cause of audit failure ${ }^{[7]}$. The analysis of audit failure in the above literatures mainly discusses the independence of auditors, the professional ability of certified public accountants, and the fraud situation of the management of the auditees. Li mochou (2017) made a comparative analysis of audit failure and audit standards, and found that "audit evidence" and "confirmation" were most violated in audit failure cases, and suggested relevant departments to intensify the modification of high-risk standards to make them more instructive in the audit process ${ }^{[8]}$. Analyzing the causes of audit failure from the perspective of audit standards can promote the audit standards committee to be targeted when formulating relevant standards and reduce the occurrence of audit failure.

(iii) preventive measures against audit failure The research on the prevention of audit failure is mainly discussed from the Angle of audit subject and audit environment. Liu hongyu (2012) prevented the occurrence of audit failure from the aspects of auditors' professional ethics, the incentive and restraint of CPA industry and the improvement of CPA's professional ability ${ }^{[9]}$. Ding hongyan (2013), through a comparative study of financial fraud and audit failure, believes that audit working papers of accounting firms should be inspected from the supervision of regulatory departments to improve the timeliness and punishment intensity of audit failure punishment ${ }^{[10]}$. Long xiaohai and zhang yuanyuan (2016) conducted an empirical study on the relationship between the size of accounting firms and audit quality, and found that there was a positive correlation between the size of branch offices and audit quality. The "big four" could better maintain their independence in the audit process and thus provide better audit reports [11].Research on prevention of audit failure domestic scholars mostly put forward countermeasures and Suggestions from the perspective of audit subjects, namely accounting firms and certified public accountants. In terms of audit environment, they mainly focus on the guidance of policies and the improvement of standards. There are many research literatures on audit quality. The improvement of audit quality can also reduce the occurrence of audit failure. The formulation of preventive measures for audit failure can also be considered from the perspective of audit quality improvement, and more feasible measures can be put forward.

\section{Research design and sample data sources}

This paper selects the punishment documents of audit failure published on the website of China securities regulatory commission from 2007 to 2017, and selects 39 punishment documents of accounting firms, involving 107 certified public accountants. The audit objects selected in this paper are all listed companies, and the audit failure facts in the punishment documents are sorted out to sort out the punishment basis of CSRC. In order to verify the relationship between the size of accounting firms and audit failure, this paper sorted out the ranking of accounting firms' business income from 2007 to 2017 published on the website of Chinese institute of certified public accountants. Due to the inevitable connection between audit 
failure and financial fraud, this paper also sorted out the performance of accounting information distortion of listed companies from the website of China securities regulatory commission. Audit failures show different proportions in specific years, as shown in table 1.

Table 1: The summary of audit failure penalties of accounting firms in China securities regulatory commission 2007-2017

\begin{tabular}{llllll}
\hline Year & Subject of punishment (individual) & Proportion (\%) & Year & Subject of punishment (individual) & Proportion (\%) \\
\hline 2007 & 2 & $5.13 \%$ & 2013 & 6 & $15.38 \%$ \\
2008 & 6 & $15.38 \%$ & 2014 & 4 & $10.26 \%$ \\
2009 & 4 & $10.26 \%$ & 2015 & 1 & $2.56 \%$ \\
2010 & 3 & $7.69 \%$ & 2016 & 4 & $10.26 \%$ \\
2011 & 2 & $5.13 \%$ & 2017 & 6 & $15.38 \%$ \\
2012 & 1 & $2.56 \%$ & summation & 39 & $100 \%$ \\
\hline
\end{tabular}

In the analysis of audit failure punishment standard, each audit failure of punishment files documents, this paper draws on li mochou(2017) will be involved in a number of auditing analysis method, from the securities and futures standards, 111 observation points were formed, commission announced penalty file, the penalty involves the specific standards of shown in the for each file analysis involved in punishment, following table.

matters shall be recorded for violating audit

Table 2 summary of frequency of code violations

\begin{tabular}{|c|c|c|c|c|c|}
\hline Code name & Number & Proportion & Code name & Number & Proportion \\
\hline $\begin{array}{l}\text { Objectives and general principles for the audit of } \\
\text { financial statements }\end{array}$ & 10 & $9.01 \%$ & Letter of certificate & 27 & $24.32 \%$ \\
\hline Audit working papers & 3 & $2.70 \%$ & Analysis program & 11 & $9.91 \%$ \\
\hline $\begin{array}{l}\text { Fraud-related liability in the audit of financial } \\
\text { statements }\end{array}$ & 4 & $3.60 \%$ & The audit sampling & 1 & $0.90 \%$ \\
\hline $\begin{array}{l}\text { Communication between former and future } \\
\text { certified public accountants }\end{array}$ & 1 & $0.90 \%$ & The affiliated party & 5 & $4.50 \%$ \\
\hline $\begin{array}{l}\text { Identify and assess material misstatement risks } \\
\text { by understanding the audited entity and its } \\
\text { environment }\end{array}$ & 4 & $3.60 \%$ & $\begin{array}{l}\text { Form audit opinions on } \\
\text { financial statements and } \\
\text { issue audit reports }\end{array}$ & 3 & $2.70 \%$ \\
\hline $\begin{array}{l}\text { Response to the assessed risk of material } \\
\text { misstatement }\end{array}$ & 5 & $4.50 \%$ & Subsequent events & 4 & $3.60 \%$ \\
\hline $\begin{array}{l}\text { Evaluate misstatements identified during the } \\
\text { audit process }\end{array}$ & 2 & $1.80 \%$ & Expert work & 1 & $0.90 \%$ \\
\hline Audit evidence & 22 & $19.82 \%$ & $\begin{array}{l}\text { The beginning balance of an } \\
\text { initial audit engagement }\end{array}$ & 3 & $2.70 \%$ \\
\hline $\begin{array}{l}\text { Specific considerations for obtaining audit } \\
\text { evidence for specific items such as inventories }\end{array}$ & 3 & $2.70 \%$ & Planning audit work & 1 & $0.90 \%$ \\
\hline $\begin{array}{l}\text { The importance of planning and performing } \\
\text { audits }\end{array}$ & 1 & $0.90 \%$ & summation & 111 & $100 \%$ \\
\hline
\end{tabular}

Is there a relationship between audit failure and accounting firm? In order to verify the audit 
failure and the relationship between the the accounting firm, and according to the China accounting firms, this article choose to association of certified public accountants determine from the accounting firm scale, annual revenue ranking as the judgment compiled in the securities and futures standard, to income in the top 10 big accounting commission punishment documents appear in firm, through sorting punished firm information.

\section{Table 3 information of accounting firms punished by CSRC}

\begin{tabular}{|c|c|c|c|c|c|c|c|}
\hline Firm name & $\begin{array}{l}\text { Number of } \\
\text { punishment }\end{array}$ & Is it big firm & Proportion & Firm name & $\begin{array}{l}\text { Number of } \\
\text { punishment }\end{array}$ & $\begin{array}{l}\text { Is it } \\
\text { big firm }\end{array}$ & Proportion \\
\hline $\begin{array}{l}\text { Xinyong zhonghe } \\
\text { accounting firm }\end{array}$ & 1 & $\mathrm{~N}$ & $2.56 \%$ & $\begin{array}{l}\text { Shenzhen pengcheng } \\
\text { accounting firm }\end{array}$ & 7 & $\mathrm{~N}$ & $17.95 \%$ \\
\hline $\begin{array}{l}\text { Leanda certified } \\
\text { public accountants }\end{array}$ & 7 & $\mathrm{~N}$ & $17.95 \%$ & $\begin{array}{l}\text { Asia Pacific (group) } \\
\text { accounting firm }\end{array}$ & 1 & $\mathrm{~N}$ & $2.56 \%$ \\
\hline $\begin{array}{l}\text { Zhongxinghua } \\
\text { accounting firm }\end{array}$ & 1 & $\mathrm{~N}$ & $2.56 \%$ & $\begin{array}{l}\text { Dahua certified public } \\
\text { accountants }\end{array}$ & 1 & $\mathrm{Y}$ & $2.56 \%$ \\
\hline $\begin{array}{l}\text { Ruihua accounting } \\
\text { firm }\end{array}$ & 3 & $\mathrm{Y}$ & $7.69 \%$ & $\begin{array}{l}\text { Zhong lei accounting } \\
\text { firm }\end{array}$ & 2 & $\mathrm{~N}$ & $5.13 \%$ \\
\hline $\begin{array}{l}\text { Beijing xinghua } \\
\text { accounting firm }\end{array}$ & 1 & $\mathrm{~N}$ & $2.56 \%$ & $\begin{array}{l}\text { Daxin certified public } \\
\text { accountants }\end{array}$ & 1 & $\mathrm{~N}$ & $2.56 \%$ \\
\hline $\begin{array}{l}\text { Lixin certified public } \\
\text { accountants }\end{array}$ & 1 & $\mathrm{~N}$ & $2.56 \%$ & $\begin{array}{l}\text { Beijing zhong tian hua } \\
\text { zheng accounting firm }\end{array}$ & 1 & $\mathrm{~N}$ & $2.56 \%$ \\
\hline $\begin{array}{l}\text { Beijing tianhua } \\
\text { accounting firm }\end{array}$ & 1 & $\mathrm{~N}$ & $2.56 \%$ & $\begin{array}{l}\text { Zhongxing caiguanghua } \\
\text { accounting firm }\end{array}$ & 1 & $\mathrm{~N}$ & $2.56 \%$ \\
\hline $\begin{array}{l}\text { Huayin accounting } \\
\text { firm }\end{array}$ & 1 & $\mathrm{~N}$ & $2.56 \%$ & Arthur Andersen LLP & 1 & $\mathrm{~N}$ & $2.56 \%$ \\
\hline $\begin{array}{l}\text { Nanjing lixin } \\
\text { yonghua accounting } \\
\text { firm }\end{array}$ & 1 & $\mathrm{~N}$ & $2.56 \%$ & $\begin{array}{l}\text { Wan long accounting } \\
\text { firm }\end{array}$ & 1 & $\mathrm{~N}$ & $2.56 \%$ \\
\hline $\begin{array}{l}\text { Fujian lixin mindu } \\
\text { accounting firm }\end{array}$ & 1 & $\mathrm{~N}$ & $2.56 \%$ & Yuehua accounting firm & 2 & $\mathrm{~N}$ & $5.13 \%$ \\
\hline $\begin{array}{l}\text { Tianjian guanghua } \\
\text { accounting firm }\end{array}$ & 1 & $\mathrm{~N}$ & $2.56 \%$ & $\begin{array}{l}\text { Shenzhen dahua } \\
\text { tiancheng accounting } \\
\text { firm }\end{array}$ & 1 & $\mathrm{~N}$ & $2.56 \%$ \\
\hline $\begin{array}{l}\text { Shandong } \\
\text { zhengyuan hexin }\end{array}$ & 1 & $\mathrm{~N}$ & $2.56 \%$ & summation & 39 & & $100 \%$ \\
\hline
\end{tabular}

Iv. Analysis of reasons for audit failure Auditing standards are what certified public accountants need to follow strictly in the process of auditing. In the stage of audit IJIBM: http://escipub.com/international-journal-of-industrial-and-business-management/ planning, the effective implementation of the pre-audit work is related to the degree of cooperation of the auditees; In the process of audit implementation, audit standards, as a 
guide to action, determine the authenticity and reliability of audit working papers and audit reports; At the stage of completion of audit, the quality of audit report depends on whether the CPA firm and the CPA can maintain due prudence and independence. To sum up, in the process of audit, audit quality is affected by audit standards, auditees and accounting firms.

(i)The audit failure and audit standards

Forster, the American neo-institutionalist of the 1970 s thought that there is a causal relationship between economic and institutional problems, Wu shuang(2010) from the perspective of audit practice, in 2006 China auditing standards for research, discover new auditing standards introduce risk-oriented audit, changed the original model of audit and audit process, beneficial to the promotion of audit quality [12]. Zhang shengli (2011) took non-financial listed companies in Shanghai and shenzhen as research objects, collected data from 2004 to 2009 as research samples, analyzed the relationship between old and new auditing standards and audit quality, and concluded that new auditing standards can improve audit quality [13]. Auditing standards in China has experienced three times a substantial adjustment, led by the ministry of finance in 1995, issued the first batch of certified public accountants independent auditing standards, in 2003 the original independent audit criterion was revised and issued to the public before and after the independent auditing standards no. 28 - as a certified public accountant of communication ", after nearly 10 years of revision and improvement of basic framework formed the independent auditing standards system in China. After the 2008 financial crisis, the accounting information quality of accounting information users and the public decision-making information content, the audit report, audit report useful questions, in order to improve the quality of audit, the audit and verification standards board formulated the "ISA 701 - in the independence of certified public accountants report key communications", and revised the "ISA 260, ISA 570, ISA 700, ISA, ISA 706, ISA 720, 705 and six auditing standards.

The revision and improvement of audit standards is to improve the audit quality. The analysis of audit failure cases can find out the audit standards that certified public accountants are most likely to violate in the audit process. The revision and improvement of the standards will play a more significant role in improving the audit quality. In the analysis of the audit failure punishment documents, according to the data of the punishment decision written by the CSRC, the summary table of the violation frequency of the standards in table 2 is obtained after sorting. According to the rules, the order of the frequency of violation is: "Audit evidence CSA 1301 " violated 22 times, "verification CSA 1312" violated 27 times, "financial statement audit objectives and general principles CSA 1101" violated 10 times, "analysis procedures CSA 1313" violated 11 times, "related party CSA 1323" violated 5 times, "period matters CSA 1332 " and other standards violated 4 times, "CSA 1501 for the formation of audit opinions on financial statements and the issuance of audit reports", "CSA 1131 for audit working papers", "specific consideration for the acquisition of audit evidence for specific items such as inventories", "CSA 1311", "CSA 1331 for the beginning balance involved in the first audit business" have committed three violations. "CSA 1153," "CSA 1314," "CSA 1421," "CSA 1221," "CSA 1201," etc."Audit evidence" and "verification" are important links to form the audit working paper. China's audit standards describe audit evidence and verification in 
general principles, objectives and requirements respectively in "audit evidence" (CSA 1301) and "verification" (CSA 1312). From the requirements in the standards, there are not many specific requirements for audit evidence and verification, such as the logicality of audit evidence chain, the diversity of verification methods and the lack of means to analyze and investigate based on the current big data information. In order to verify the audit failure and auditing standards is affected by conditions such as the new technology, the audit failure violation of auditing standards in order to analyses the time dimension, can be seen from the figure 1 in addition to "the approaches for the evaluation of material misstatement risk response", "letter of certificate" and "analysis program, the frequency of the other criteria are has increased in recent years. In the face of changes in new forms of technology and the economic environment, the number of audit failures is also increasing, especially in the cases of audit failures in 2016 and 2017, the violation of audit standards is also increasing.

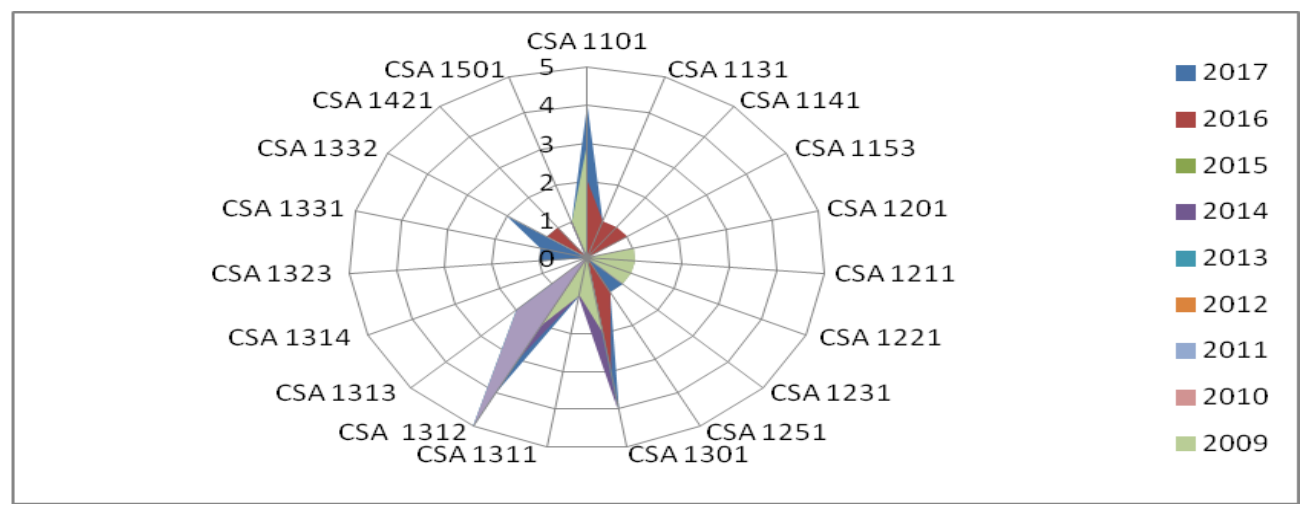

Figure 1. Time-dimensional analysis of auditing standard violations

\section{(ii) Audit failure and size of the firm}

What is the relationship between audit failure and accounting firm size? In order to study the relationship between the two, the relationship between audit quality and accounting firm size can be compared. Domestic and foreign scholars mainly study audit quality from an overall perspective and believe that there is a positive correlation between audit quality and accounting firms. From the perspective of earnings manipulation, Choi, Kim (2010) et al. took the absolute value of controllable accruals as the alternative variable of audit quality, and found that firm size can significantly improve audit quality [14]. Francis and Yu (2009) et al. found that in the provision of authentication business, the "big four" branch of accounting firms had high professional competence and rich experience in auditing, so the audit quality was guaranteed. The "big four" have a good reputation and stable customer group in the market. According to the theory of reputation maintenance motivation, the improper behaviors of the "big four" in the audit have a huge impact on their reputation [15].

In this paper, the scale of accounting firms is defined according to the income in the comprehensive evaluation data of accounting firms issued by the Chinese institute of certified public accountants every year. The punishment decision letter issued by the CSRC shall be sorted out. It was found that among the 22 audit failures, the penalty proportion of big audit failures was $10.25 \%$, and the penalty proportion 
of non-big audit failures was $89.75 \%$. Through can provide high-quality audit reports in the the comparison of data, it can be seen that daxi audit process.

Table 4 proportion of punishment times of different accounting firms

\begin{tabular}{lll}
\hline Type of accounting firm & Number of penalties & proportion of the total number of penalties \\
\hline Big firm & 4 & $10.25 \%$ \\
Other types & 35 & $89.75 \%$ \\
\hline
\end{tabular}

The above data analysis verified the theory of "deep pocket" again, the "big four" accounting firms to audit process, has the good professional competence, in order to avoid audit failure cost litigation firm, "big four" accounting firms process more attention to the reputation of the maintenance and management than the "non-big four" accounting firms to audit. In order to cater to the auditees and reduce costs, the "non-big four" accounting firms published inappropriate audit reports, which led to the failure of the audit. The proportion of the punishment of the "non-big four" accounting firms in the CSRC remained high, especially the
REANDA accounting firms.

(iii) audit failure and financial fraud

In the process of auditing, certified public accountants often have information asymmetry with the auditee. Is there an inevitable connection between financial fraud and audit failure? How to identify the financial fraud of the auditee and improve the audit quality? Manually sort out the information of companies punished by CSRC for financial fraud from 2007 to 2017 through the website of CSRC. In ten years, CSRC has punished 125 companies, including 2 IPO companies.

Table 5 summary of financial fraud and audit failure

\begin{tabular}{llll}
\hline Year of punishment & Amount of financial fraud & Number of audit failures & Percentage of audit failures \\
\hline 2017 & 21 & 6 & $28.57 \%$ \\
2016 & 10 & 4 & $40.00 \%$ \\
2015 & 7 & 1 & $14.29 \%$ \\
2014 & 12 & 4 & $33.33 \%$ \\
2013 & 5 & 6 & $120.00 \%$ \\
2012 & 9 & 1 & $11.11 \%$ \\
2011 & 8 & 2 & $25.00 \%$ \\
2010 & 10 & 3 & $30.00 \%$ \\
2009 & 9 & 4 & $44.44 \%$ \\
2008 & 13 & 6 & $46.15 \%$ \\
2007 & 21 & 2 & $9.52 \%$ \\
Total & 125 & 39 & $31.20 \%$ \\
\hline
\end{tabular}

SPSS2.0 was used to analyze the correlation between the number of financial fraud and the 
number of audit failures. The correlation between the number of financial fraud and the number of audit failures was $18.74 \%$, suggesting that there is no necessary connection between the number of financial fraud and audit failures. According to the punishment decision for accounting firms and enterprises published by China securities regulatory commission from 2007 to 2017, the punishment for enterprises is 125 times, the punishment for accounting firms is 39 times, and the audit failure rate is $31.20 \%$, which means that certified public accountants will audit the listed companies and issue appropriate audit reports is $68.8 \%$. The analysis of financial fraud and audit failure should be further based on the duration of both. Financial fraud led by the management brings great obstacles to the audit work, and it is very beneficial to the improvement of audit quality to find out and put an end to financial fraud.

(i) conclusion

Through the study of the punishment decision form from 2007 to 2017 published on the website of China securities regulatory commission, it is found that :(1) in the punishment decision form of audit failure published by China securities regulatory commission, there are many rules of "audit evidence" (CSA 1301) and "confirmation" (CSA 1312 ), accounting for $44.14 \%$. (2) the scale of the accounting firm has a great impact on the audit quality. In the audit failure decision book, the penalty rate of "non-big firm" is $89.75 \%$. In particular, the penalty rate of lianda accounting firm and shenzhen pengcheng accounting firm is $35.9 \%$. (3) there is no necessary connection between financial fraud and audit failure. However, in the process of audit, certified public accountants can accurately identify financial fraud, which can improve audit quality and reduce the occurrence of audit failure.

(ii) preventive strategies

1. In view of the audit standards frequently violated in the punishment of audit failure, the Chinese institute of certified public accountants needs to pay special attention to the revision of audit standards, and the standards should be formulated in accordance with the needs of audit work, with appropriate details. Auditing standards are the guiding documents of auditing work. The auditing standards committee should pay close attention to the changes of international auditing standards, constantly update the contents of auditing standards, and ensure the convergence with international auditing standards.2, The influence of the certified public accountants to audit failure is bigger, especially small and medium-sized accounting firms to lock customers, malicious reduce audit fee, and the auditees formed between the close relation, lead to accounting firm independence challenged, when performing audit procedures due to the low audit fees or under the control of the management of the auditees, issue false audit report, a lot of negative effects for certified public accountants industry. In order to improve the audit quality, the Treasury can establish a folk audit funds from across the country, the ministry of finance to collecting and compiling the national qualified CPA firm, uniform distribution of authentication business, need according to the size of listed companies in certain audit fee, all audit cost summary to the folk audit funds, directly by the Treasury will audit fee transfer to the corresponding audit institutions. If there is any audit failure in the audit process, the punishment should be increased to ensure the improvement of audit quality.3. Although financial fraud cannot directly lead to the occurrence of audit failure, 
the occurrence of financial fraud does have some impact on the audit work. In order to eliminate the negative impact of financial fraud on audit work, the management level of the auditee should earnestly perform their duties, strengthen the internal control construction of the enterprise, improve the independent director system, and reduce or even eliminate the occurrence of financial fraud. Certified public accountants should improve their professional competence and professional doubt ability, strictly implement the audit procedures in the audit process, and pay attention to the communication with the relevant personnel of the audited units.

\section{References}

1. zheng zhaohui. Analysis and investigation research on ten management fraud cases of listed companies [J]. Audit research, 2001(6):22-24.

2. Chen xi. Analysis of reasons for audit failure and preventive measures [J]. Oriental corporate culture,2012(11):92-93.

3. De Angelo, L.E. Auditor Size and Audit Quality[J]. Journal of Accounting and Economics.1981 (03) : 183-199.

4. Chen hanwen, wang hua, zheng xincheng Andersen: events and reflections [M] Guangzhou: jinan university press,2003.35-51.

5. ma LAN, wang yanming. Business failure, audit failure and audit risk -- analysis of experience from suspended listed companies' annual audit reports [J]. China certified public accountant,2003(03):23-25.

6. li ruoshan. Audit failure and COSO report -- on enterprise innovation and internal control changes [J]. Audit and economic research, 2005 (02) :3-7.

7. li ping, wang xiaomin. The status quo of audit failure of listed companies and preventive measures $[\mathrm{J}]$. Economics and management.2014(9) : 8-9.

8. Ii mochou. Audit standards and audit failure -based on the scores of administrative punishment announcements made by China securities regulatory commission over the years [J]. Audit and economic research,2017(02):1-10.

9. liu hongyu. On the audit failure of CPA [J]. China foreign capital,2012 (21):181.

10. ding hongyan, audit failure and its consequences -- an analysis based on the punishment announcement of China securities regulatory commission from 2006 to 2010 [J]. Journal of ocean university of China, 2013 (1) :62-67.

11. long xiaohai, zhang yuanyuan. Scale and audit quality of accounting firms -- an empirical study based on the branches of accounting firms [J]. Journal of nanjing audit university, 2016 (05) :92-105.

12. wu shuang. On the characteristics of audit standards 2006 and its impact on audit practice [J]. China management informatization.2010(7):45-49.

13. zhang shengli. Does the new auditing standard improve the auditing quality? Journal of shanxi university of finance and economics.2011(8):108-114.

14. Cho,Chansog Kim ,Jeong-Bon Kim, and Zang .Audit Office Size ,Audit Quality,and Dudit Pricing[J].Auditing:A Journal of Pratice\&Theory,2010,29(1):73-79.

15. FRANCIS J R, YU M D.Big 4 Office Size and Audit Quality $[\mathrm{J}]$. The Accounting Review, 2009(84): 521-1550.

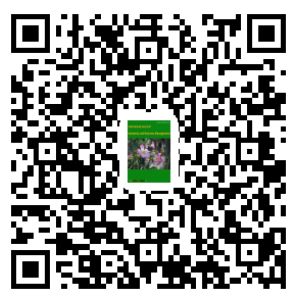

